Pak. j. sci. ind. res. Ser. B: biol. sci. 201356 (2) 70-75

\title{
Growth and Yield Characteristics of Chilli as Affected by Nitrogen in Presence and Absence of Phosphorus and Potassium
}

\author{
Parwaiz Ahmed Baloch ${ }^{a *}$, Bashir Ahmed Abrob, Abdul Hameed Solangia \\ and Aqeel Ahmed Siddiqui ${ }^{\mathrm{a}}$

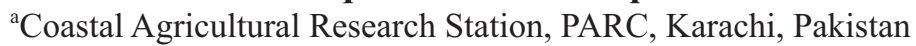

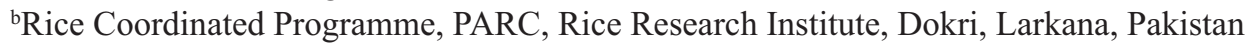

(received October 18, 2011; revised October 9, 2012; accepted December 27, 2012)

\begin{abstract}
An effect of nitrogen (N) in presence and absence of phosphorus (P) and potassium (K) on growth and yield characteristics of chilli (Capsicum annum L.) was studied at Coastal Agricultural Research Station, Southern Zone Agricultural Research Centre, PARC, Karachi, during 2008-2009. The crop under investigation was fertilized with a total of six treatments i.e. 90-0-0, 90-60-75, 0-60-75, 120-0-0, 120-90105 and $0-90-105 \mathrm{~kg} / \mathrm{ha}$ of NPK. The analyses of data revealed that it was possible to harvest a satisfactory crop yield without addition of $\mathrm{P}$ or $\mathrm{K}$, but it would not be possible to get desired crop yields without application of $\mathrm{N}$, because an adverse effect on fruit yield was noted in absence of $\mathrm{N}$. On the other hand stoppage of $\mathrm{P}$ and $\mathrm{K}$ did not show any economically adverse effects. However, combined application of NPK positively enhanced growth and yield characters. It was concluded that $\mathrm{N}$ in presence of $\mathrm{P}$ and $\mathrm{K}$ (120$90-105 \mathrm{~kg} / \mathrm{ha}$ ) proved best for better production of chilli var. Malir local under agro climatic conditions of Malir district, Sindh.
\end{abstract}

Keywords: chilli, growth, yield, fertilizer, nitrogen, phosphorus, potassium

\section{Introduction}

Chilli (Capsicum anmum L.) belongs to the family Solanaceae. Chilli has a wide range of cultivation, being grown under both tropical and subtropical conditions (Malik, 1994). In Pakistan chilli is grown on an area of 38.4 thousand hectares with production of 90.4 thousand tonnes, with an average yield of 1.7 tonnes per hectare with $1.5 \%$ share in the GDP. Sindh is the major producer of chilli (70\%) followed by Punjab (25\%) and remaining $5 \%$ is produced by Balochistan and NWFP provinces (Mahmood et al., 2002). Chilli is not only an important ingredient in food but is also used for essence production. It is used in foods for pungency and red colour while, it also contributes in part to the flavour of ginger ales. Chilli is an excellent source of vitamins A, B, C, E, P and high in antioxidants. Pakistan earned Rs.1.127 billion during 2003-2004 by exporting red chilli powder, whereas, export earnings from all fruits were Rs. 5.912 billion during the same period. This reveals the potential of this non-staple crop. There are various factors responsible for the low yield of chilli in Sindh province as compared to other advanced agricultural countries of the world. Among them one of the most important cause is the under dosage of major essential nutrients such as $\mathrm{N}, \mathrm{P}$ and $\mathrm{K}$ in the cultivating soils.

*Author for correspondence; E-mail: pervezparc@gmail.com
Crops respond differently to different fertilizer elements, and proper fertilizer management for a plant species is important for increasing yield and quality. Nitrogen, phosphorus and potassium are the three major nutrients, which individually and/or together maintain growth, yield and quality of plants (Kodali, 2006). Nitrogen is involved in chlorophyll formation and it influences stomatal conductance and photosynthetic efficiency (Ivonyi et al., 1997). Phosphorus stimulates root development and promotes flower formation and fruit production (Malik et al., 2006). Particularly, it is considered essential for seed formation. It hastens maturity of crops grown on soils low in phosphorus. Phosphorus indirectly promotes plant growth and absorption of $\mathrm{K}$ as well as other nutrients (McKenzie et al., 2002). Potassium plays catalytic role in the plant rather than becoming an integral part of plant components (Malvi, 2011). It regulates the permeability of cell walls and activities of various mineral elements as well as neutralizes physiologically important organic acids (Britto and Kronzucker, 2008). Plants with an inadequate supply of K show poor fruit or seed formation (Bartall and Pressman, 1996), yellowing of the leaves, poor growth, and low resistance to coldness and drought (Asgharipour and Heidari, 2011). A sufficient supply of K promotes $\mathrm{N}$ uptake efficiency of plants due to its stimulant effect on plant growth (Malik et al., 1989). 
In earlier work, conducted by Naeem et al. (2002) reported that different doses of NPK were significantly different for days to flowering, fruit characters and total yield in chilli. Vadhana (2003) revealed that the maximum number of fruits per plant (78.73/plant), highest green chilli yield (175.43 g/plant) and higher fruit yield $(5957 \mathrm{~kg} / \mathrm{ha})$ was recorded in the higher fertilizer level (250:125:125 NPK kg/ha) than fertilizer level (150:75:75 NPK kg/ha). The results obtained by Miano et al. (2004) regarding effect of different doses of $\mathrm{N}$ and $\mathrm{K}_{2} \mathrm{O}$ on chilli indicated that application of $120 \mathrm{~kg} / \mathrm{ha} \mathrm{N}$ and $125 \mathrm{~kg} / \mathrm{ha}$ of $\mathrm{K}_{2} \mathrm{O}$ proved best for vigorous growth and fruit yield than all other treatments. In a field trial, Baloch et al. (2004) found NPK level of $83-78-73 \mathrm{~kg} / \mathrm{ha}$ highly significant on the growth, yield and yield components of chilli describing the importance of balanced supply of nutrients. The results obtained by Ramakrishna and Palled (2005) revealed that fruit yield and total dry matter production of chilli was significantly higher with the application of 150:75: $75 \mathrm{~kg} / \mathrm{ha}$ of $\mathrm{N}, \mathrm{P}_{2} \mathrm{O}_{5}$ and $\mathrm{K}_{2} \mathrm{O}$ (2:1:1) over other fertilizer levels. Din et al. (2007) reported that NPK levels of $120-90-60 \mathrm{~kg} / \mathrm{ha}$ significantly performed better with growth, marketable yields and head yield of cabbage. Jilani et al. (2008) reported that nitrogen application at $100 \mathrm{~kg} / \mathrm{ha}$ produced significantly maximum survival percentage, fruit characters and yield per hectare in brinjal. While, Yahaya (2008) reported that productivity in chilli pepper could be enhanced with efficient fertilization. The non-significant response exhibited by some parameters could be due to their inherent character that is genetically controlled rather than being influenced by management (Ahmad et al., 2009). Keeping in view the importance of fertilizer management, it is necessary to educate our farmers regarding balanced use of fertilizers. The present experiment was conducted to evaluate the growth and yield characteristics of chilli as affected by nitrogen in presence and absence of phosphorus and potassium under agro-climatic conditions of Malir district, Karachi, Pakistan.

\section{Materials and Methods}

The experiment was conducted to find out the optimum dose of $\mathrm{N}, \mathrm{P}$ and $\mathrm{K}$ and to evaluate the impact of nitrogen in presence and absence of phosphorus and potassium on the growth and yield characteristics of chilli during 2008-2009. Seed of Malir local variety was sown in well-prepared and manured plot in the experimental field of Coastal Agricultural Research Station, Southern Zone Agricultural Research Centre, PARC, Karachi.
Germination was found satisfactory. The experiment was laid out in RCBD replicated four times maintaining plot size of $2.5 \mathrm{~m} \times 3 \mathrm{~m}$ for all treatments. The NPK treatments tested during the study were comprised of T1 90-00-00, T2 90-60-75, T3 00-60-75, T4 120-0000, T5 120-90-105 and T6 00-90-105 NPK kg/ha. At least six weeks old seedlings were transplanted in main field on both sides of ridges with plant to plant and row to row distance of $60 \mathrm{~cm}$. Before transplanting the seedlings, land was prepared and at that time all $\mathrm{P}$ and $\mathrm{K}$ fertilizers along with half dose of $\mathrm{N}$ were added and mixed well in the soil before irrigating the ridges for transplanting. The remaining $\mathrm{N}$ was applied subsequently in three equal doses at 15, 30 and 45 days after planting (DAP) due to the light texture of the soil. Nitrogen was applied in the form of Urea $(46 \% \mathrm{~N})$, while phosphorus and potassium were used in the form of single super phosphate $\left(18 \% \mathrm{P}_{2} \mathrm{O}_{5}\right)$ and potassium sulphate $(50 \%$ $\mathrm{K}_{2} \mathrm{O}$ ), respectively to get the required doses according to recommended treatments schedule. All the cultural operations like weeding, hoeing and irrigation were carried out uniformly in all the treatments as and when needed for better growth and development of the crop.

Soil analysis. The composite soil samples from experimental site were taken at two depths $(0-15$ and $15-30 \mathrm{~cm})$. These samples were air-dried, ground, sieved and then analyzed for various physical and chemical characteristics of soil. The soil texture was determined with hydrometer as per method described by Bouyoucos (1962) and $\mathrm{pH}$ in soil water suspension (1:5) was determined with glass electrode $\mathrm{pH}$ meter (SP-34 Suntex) by Richards (1954). EC was determined with digital (HI-8333) conductivity meter (Kanwar and Chopra, 1959). Organic matter was determined by Walkely and Black procedure as suggested by Jackson (1958). Nitrogen was determined by Macro-Kjeldahl method (Paul and Berry, 1921). Available phosphorus was determined by the method described by Soltanpur and Schwabe (1977) and potassium by AB-DTPA method as suggested by Soltanpur and Schwabe (1985).

Data collection and statistical analysis. Five plants in each bed were selected at random and labeled for recording observations on germination percentage (\%), plant height $(\mathrm{cm})$, number of branches/plant, days to flowering, days to fruiting, fruits/plant, fruit diameter $(\mathrm{cm})$, fruit length $(\mathrm{cm})$, fruit weight/plant $(\mathrm{g})$ and total fruit yield $(\mathrm{kg} / \mathrm{ha})$ during the growth and after harvest of the crop. The data thus collected were subjected to statistical analysis to analyze the treatments variance. 
L.S.D test was also applied to observe the statistical differences according to the method developed by Gomez and Gomez (1984).

\section{Results and Discussion}

Physico-chemical characteristics of experimental site. Physical as well as chemical characteristics data of the experimental area soil is presented in Table 1. The data revealed that the soil was sandy clay loam in texture, low in organic matter content (\%), deficient in nitrogen and phosphorus but contained sufficient amount of available potassium. The $\mathrm{pH}$ of the surface and sub soil layers was of 7.5 and 7.7 , respectively.

Table 1. Physico-chemical analyses of soil of the experimental field

\begin{tabular}{lll}
\hline \hline Soil characteristics & \multicolumn{2}{c}{ Depth $(\mathrm{cm})$} \\
\cline { 2 - 3 } & $0-15$ & $15-30$ \\
\hline EC $(\mathrm{dS} / \mathrm{m})$ & 4.73 & 1.92 \\
$\mathrm{pH}$ & 7.5 & 7.7 \\
$\mathrm{O} . \mathrm{M}(\%)$ & 0.619 & 0.222 \\
$\mathrm{~N}(\%)$ & 0.030 & 0.011 \\
$\mathrm{P}(\mathrm{ppm})$ & 4.0 & 1.9 \\
$\mathrm{~K}(\mathrm{ppm})$ & 100 & 110 \\
Texture & Sandy clay & Sandy clay \\
& loam & loam \\
\hline \hline
\end{tabular}

Data regarding the effect of nitrogen in presence and absence of $\mathrm{P}$ and $\mathrm{K}$ on the growth and yield characteristics of chilli as recorded are given:

Plant height $(\mathbf{c m})$. Mean plant height $(75.4 \mathrm{~cm})$ was significantly greater in the plots fertilized with 120-90$105 \mathrm{NPK} \mathrm{kg} / \mathrm{ha}$, followed by $120-0-0$ and $90-0-0 \mathrm{NPK}$ $\mathrm{kg} / \mathrm{ha}$ with mean plant height of $73.53 \mathrm{~cm}$ and 71.66 $\mathrm{cm}$, respectively (Table 2). The plots treated with 0-60$75 \mathrm{NPK} \mathrm{kg}$ /ha had shorter plants $(64.66 \mathrm{~cm})$ as compared to plots where $\mathrm{N}$ was applied alone (90-0-0) or $\mathrm{N}$ was applied with P and K 90-60-75 kg/ha. The height of chilli plants progressively increased from $64.66 \mathrm{~cm}$ up to $75.64 \mathrm{~cm}$ as crop received increasing fertilizer dose. The minimum plant height might be due to the unavailability of essential nutrients required by the plants for their proper growth. On the other hand increasing plant height with $\mathrm{N}$ was probably because of the role of $\mathrm{N}$ in cell division and cell enlargement, which ultimately affected the vegetative growth particularly height of the plant. These results resemble with that of Olanrewaju and Showemino (2003) who found an improvement in plant height with increasing nitrogen application.

Number of branches/plant. Comparatively more number of branches (3.42) recorded when N, P and K were applied at the rate of 120-60-105 NPK kg/ha. The results further demonstrated that with the combination of NPK levels, an increase in number of branches was observed. While, minimum number of branches (2.52) were obtained in plots which received $\mathrm{P}$ and $\mathrm{K}$ only at the rate of 00-60-75 NPK kg/ha. Earlier studies conducted regarding effect of nitrogen state that it has significant effect on the vegetative growth which ultimately results in an increase in number of branches per plant (Sajid et al., 2001; Singh et al., 1999). The results are in support with the findings of Suresh (2000) who concluded that combined application of 100:50:75 $\mathrm{N}, \mathrm{P}_{2} \mathrm{O}_{5}$ and $\mathrm{K}_{2} \mathrm{O} \mathrm{kg} /$ ha produced significantly higher number of branches/plant over other fertilizer levels.

Days to flowering. Data on days to flowering showed that minimum days to flowering (48.66 days) were recorded in plots where fertilizer level was at 120-60$105 \mathrm{NPK} \mathrm{kg} / \mathrm{ha}$, followed by (50.00 days) at fertilizer level of 00-90-105 NPK kg/ha, while maximum days to flowering (53.33 days) were recorded where $\mathrm{N}$ was applied without $\mathrm{P}$ and $\mathrm{K}$ at the rate of 90-00-00 NPK $\mathrm{kg} / \mathrm{ha}$. This might be due to the fact that high doses of nitrogen delayed flowering and enhanced vegetative growth in early stages while, phosphorus helps in flowering. Similarly Satpal and Saimbhi (2003) observed that nitrogen significantly affected flowering in two brinjal hybrids. Phosphorus enhances flowering and fruiting and an early flowering was observed where nitrogen was less and phosphorus was greater, as more nitrogen applied alone delayed flowering.

Table 2. Growth characteristics of chilli (Capsicum annum, L.) as affected by $\mathrm{N}$ in presence and absence of $\mathrm{P}$ and $\mathrm{K}$

\begin{tabular}{lllll}
\hline \hline $\begin{array}{l}\text { Treatment } \\
\text { NPK } \\
(\mathrm{kg} / \mathrm{ha})\end{array}$ & $\begin{array}{l}\text { Plant } \\
\text { height } \\
(\mathrm{cm})\end{array}$ & $\begin{array}{l}\text { Branches/ } / \\
\text { plant }\end{array}$ & $\begin{array}{l}\text { Days } \\
\text { to } \\
\text { flowering }\end{array}$ & $\begin{array}{l}\text { Days } \\
\text { to } \\
\text { fruiting }\end{array}$ \\
\hline T1 90-00-00 & 71.66 & 2.90 & 52.62 & 6.30 \\
T2 90-60-75 & 69.20 & 3.08 & 50.33 & 8.24 \\
T3 00-60-75 & 64.66 & 2.52 & 51.33 & 5.93 \\
T4 120-00-00 & 73.53 & 3.35 & 53.33 & 8.71 \\
T5 120-90-105 & 75.64 & 3.42 & 48.66 & 9.25 \\
T6 00-90-105 & 66.00 & 2.62 & 50.00 & 7.56 \\
LSD $(\mathrm{P}<0.05)$ & 2.02 & 0.22 & 1.33 & 0.14 \\
\hline \hline
\end{tabular}


Days to fruiting. The data regarding days to fruiting has been presented in Table 2. It indicates that the plants received fertilizer at the rate of $120-90-105 \mathrm{NPK} \mathrm{kg} / \mathrm{ha}$ took maximum (9.25) days to fruiting, followed by (8.71) days to fruiting where only $\mathrm{N}$ was applied at the rate of 120-00-00 NPK kg/ha, while minimum days (5.93) were taken by the plants fertilized with a dose of 00-60-75 NPK kg/ha. This is because of nitrogen as the application of nitrogen delays flowering that results in delayed fruiting. Due to high nitrogen the days to flowering and days to fruiting were delayed. These results are in close conformity to those of Sutagundi (2000) who reported that early fruiting (43.66 days) was recorded in plants received FYM (10 t/ha) as compared to NPK 100:50:50 kg/ha for the same parameter (43.75 days) in chilli.

Number of fruits/plant. The plots which had received NPK (120-90-105 kg/ha) had maximum number of fruits (111.62)/plant, followed by 120-0-0 NPK levels (99.65) fruits/plant (Table 3). While, the least number of fruits/plant (60.66) were obtained under 0-60-75 NPK levels. From the data presented in Table 3, it is clear that the combination of nutrients i.e., 120-90-105 NPK $\mathrm{kg}$ /ha gave significantly higher number of fruits (111.62) with greater weight/plant (381.82 g) under agro climatic conditions of Malir. It might be due to the effect of nitrogen in presence of phosphorus and potassium applied in sufficient and balanced amount that increased vegetative and overall growth of plants; this might increase number of fruits/plant. These results agree with the findings of Akanbi et al. (2010) who obtained maximum fruits/plant when nitrogen was applied along with phosphorus and potassium.

Table 3. Yield characteristics of chilli (Capsicum annum, L.) as affected by $\mathrm{N}$ in presence and absence of $\mathrm{P}$ and $\mathrm{K}$

\begin{tabular}{llllll}
\hline \hline $\begin{array}{l}\text { Treatment } \\
\text { NPK } \\
(\mathrm{kg} / \mathrm{ha})\end{array}$ & $\begin{array}{l}\text { No. of } \\
\text { fruits/ } \\
\text { plant }\end{array}$ & $\begin{array}{l}\text { Fruit } \\
\text { diameter } \\
(\mathrm{cm})\end{array}$ & $\begin{array}{l}\text { Fruit } \\
\text { length } \\
(\mathrm{cm})\end{array}$ & $\begin{array}{l}\text { Days } \\
\text { to } \\
\text { fruiting }\end{array}$ & $\begin{array}{l}\text { Fruit } \\
\text { yield } \\
(\mathrm{kg} / \mathrm{ha})\end{array}$ \\
\hline $\mathrm{T} 190-00-00$ & 71.96 & 3.33 & 7.56 & 191.98 & 5620.66 \\
T2 90-60-75 & 82.63 & 3.43 & 8.24 & 219.95 & 5743.33 \\
T3 00-60-75 & 60.66 & 3.00 & 5.93 & 176.33 & 5255.22 \\
T4 120-00-00 & 99.36 & 3.66 & 8.71 & 230.30 & 7386.33 \\
T5 120-90-105 & 111.62 & 3.86 & 9.25 & 381.82 & 7679.66 \\
T6 00-90-105 & 62.10 & 3.16 & 6.30 & 185.20 & 5310.33 \\
LSD $(\mathrm{P}<0.05)$ & 4.65 & 0.66 & 1.02 & 6.55 & 312.03 \\
\hline \hline
\end{tabular}

Fruit diameter $(\mathbf{c m})$. Mean fruit diameter was significantly greater $(3.86 \mathrm{~cm})$ in the plots fertilized with 120 90-105 NPK kg/ha, followed by $120-0-0$ and $90-60-75$ $\mathrm{NPK} \mathrm{kg} / \mathrm{ha}$ with mean fruit diameter of $3.66 \mathrm{~cm}$ and $3.43 \mathrm{~cm}$, respectively. The plots treated with 00-60-75 $\mathrm{NPK} \mathrm{kg} / \mathrm{ha} \mathrm{had}$ fruit diameter of $3.00 \mathrm{~cm}$. The minimum fruit diameter might be due to the unavailability of essential nutrients required by the plants for their proper growth. An improvement in fruit diameter under balanced amount of nitrogen along with phosphorus and potassium elements was mainly linked with better plant growth that caused healthier fruits with better diameter. These results are in agreement with the results of Islam et al. (2008), who observed that application of higher amount of nutrients increased vigorous plant growth, number and size of capsule as compared to farmers' practice who apply little or no fertilizer.

Fruit length (cm). The data with regard to the effect of $\mathrm{N}$ in presence and absence of $\mathrm{P}$ and $\mathrm{K}$ on size of the fruit has been expressed as length in $\mathrm{cm}$. The effect of NPK on this parameter was found positive. The size of fruit harvested/picked from plots where NPK was applied with $120-90-105 \mathrm{~kg} / \mathrm{ha}$ was larger $(9.25 \mathrm{~cm})$ in length as compared to those where $\mathrm{N}$ was applied alone at the rate of 90-0-0 NPK kg/ha had fruits of $6.30 \mathrm{~cm}$ in length. However, fruits obtained from the plots received $\mathrm{P}$ and $\mathrm{K}$ alone in absence of $\mathrm{N}$ with 0-60-75 $\mathrm{NPK} \mathrm{kg}$ /ha had minimum length $(5.93 \mathrm{~cm})$. These results are in line with that of Yahaya (2008), who observed improvement in fruit size in response of balanced amount of fertilizers. It means that recommended fertilization would affect the fruit size and other growth parameters as well.

Fruit weight/plant (g). Yield in terms of weight of fruits/plant has been presented in Table 3. The maximum yield (381.82 g/plant) was harvested from the plots which had received nitrogen $120 \mathrm{~kg} / \mathrm{ha}$ with phosphorus and potassium at 90 and $105 \mathrm{~kg} / \mathrm{ha}$ (T5) followed by 120-0-0 NPK levels (T4), where N was applied alone having $230.30 \mathrm{~g}$ of fruits/plant. The weight of fruits $(219.95 \mathrm{~g})$ harvested from plots treated with NPK with 90-60-75 kg/ha ranked at third. While, the least fruit weight ( $176.33 \mathrm{~g} / \mathrm{plant})$ was obtained from plots which were fertilized with $\mathrm{P}$ and $\mathrm{K}$ in absence of $\mathrm{N}$ (0-60-75 $\mathrm{kg} / \mathrm{ha}$ ). The combined application of $\mathrm{P}$ and $\mathrm{K}$ showed antagonistic effects on vegetative growth. $\mathrm{P}$ and $\mathrm{K}$ without $\mathrm{N}$ probably created nutrient imbalance, which resulted in an antagonistic effect on vegetative growth. Malawadi et al. (2004) reported that the application of 
FYM at 10 t/ha along with major nutrients (100:50:50 $\mathrm{NPK} \mathrm{kg} / \mathrm{ha}$ ) recorded higher fruit weight and 100 fruit weight in chilli crop.

Total yield ( $\mathrm{kg} / \mathbf{h a})$. The results exhibited that the maximum fruit yield $(7679.66 \mathrm{~kg}$ ) was obtained where nitrogen was applied along with phosphorus and potassium with a dose of 120-90-60 kg/ha (T5), followed by $120-0-0 \mathrm{~kg}$ NPK levels $(7386.33 \mathrm{~kg})$. While, the least fruit yield $(5255.66 \mathrm{~kg})$ was obtained under 0-60$75 \mathrm{~kg} / \mathrm{ha}$ NPK levels. The high yield might be due to high nitrogen, phosphorus and potassium rates. Nitrogen helps in vegetative growth, due to which branches increased and if there are more branches there may be more fruits and in turn yield will be high. Phosphorus along with nitrogen and potash also helps in improving fruit quality and enhancing flowering due to which yield is increased. These results are in agreement with the findings of Naeem et al. (2002), who reported that different dozes of NPK behaved significantly different for total yield. Likewise, Jilani et al. (2008) reported that $\mathrm{N}$ application at $100 \mathrm{~kg} / \mathrm{ha}$ significantly increased brinjal yield. It is concluded from the study that fertilizers level of 120-90-75 NPK kg/ha had significantly affected the yield and growth characteristics of chilli. The above level of fertilizers had positive effect on most of the parameters therefore, yield was increased significantly.

\section{Conclusion}

The combined application of NPK fertilizers positively affected growth and yield characteristics of chilli as compared to nitrogen applied alone. It was concluded that, $\mathrm{N}$ in presence of $\mathrm{P}$ and $\mathrm{K}$ with $120-90-105 \mathrm{~kg} / \mathrm{ha}$ proved best for better production of chilli var. Malir Local under agro climatic conditions of Malir district, Sindh, Pakistan.

\section{References}

Ahmad, S., Zia-ul-Haq, M., Ali, H., Ahmad, A., Khan, M.A., Khaliq, T., Husnain, Z., Hussain, A., Hoogenboom, G. 2009. Morphological and quality parameters of Oryza sativa L. as affected by population dynamics, nitrogen fertilization and irrigation regimes. Pakistan Journal of Botany, 41: 1259-1269.

Akanbi, W.B., Togun, A.O., Adediran, J.A., Ilupeju, E.A.O. 2010. Growth, dry matter and fruit yields components of Okra under organic and inorganic sources of nutrients. American-Eurasian Journal of Sustainable Agriculture, 4: 1-13.
Asgharipour, M.R., Heidari, M. 2011. Effect of potassium supply on drought resistance in Sorghum: Plant growth and macronutrient content. Pakistan Journal of Agricultural Sciences, 48: 197-204.

Baloch, M.A., Baloch, A.F., Baloch, Q.B., Niazi, A.N. 2004. Performance of Chilli, Capsicum annuum L. variety Talhari under varying fertility regimes. Pakistan Journal of Agriculture, Agricultural Engineering Veterinary Sciences, 20: 23-26.

Bar-Tal, A., Pressman, E. 1996. Root restriction and potassium and calcium concentrations affect by dry-matter production, cation uptake and blossomend rot in green house tomato. Journal of the American Society for Horticultural Science, 121: 649-655.

Bouyoucos, G.J. 1962. Hydrometer method improved for making particle size analysis of soils. Agronomy Journal, 54: 464-465.

Britto, D.T., Kronzucker, H.J. 2008. Cellular mechanisms of potassium in plants. Physiologia Plantarum, 133: 637-650.

Din, M., Qasim, M., Aslam, M. 2007. Effect of different levels of N, P and $\mathrm{K}$ on the growth and yield of cabbage. Journal of Agricultural Research, 45: 171-176.

Gomez, K.A., Gomez, A.A. 1984. Statistical Procedure for Agricultural Research, International Rice Research Institute Book, A Wiley Interscience, John Wiley and Sons Inc., New York, USA.

Islam, M.S., Howlader, M.I.A., Raffiquzzaman, S., Bashar, H.M.K., Al- Mamun, M.H. 2008. Yield response of Chilli and T. Aman rice to NPK fertilizers in Ganges Tidal floodplain. Journal of Soil and Nature, 2: 7-13.

Ivonyi, I., Izsoki, Z., Van der Werf, H.M.G. 1997. Influence of nitrogen supply and $\mathrm{P}$ and $\mathrm{K}$ levels of the soil on dry matter and nutrient accumulation of fiber hemp (Cannabis sativa. L.). Journal of the International Hemp Association, 4: 82-87.

Jackson, M.L. 1958. Soil Chemical Analysis. pp. 372374, Prentice Hall, Inc., Englewood, Cliff, New Jersey, USA.

Jilani, M.S., Afzal, M.F., Waseem, K. 2008. Effect of different nitrogen levels on growth and yield of brinjal. Journal of Agricultural Research, 46: 245251.

Kanwar, T.S., Chopra, S.L. 1959. Practical Agricultural Chemistry. S. Chand and Co., Delhi, India.

Kodalli, S.H. 2006. Studies on integrated nutrient management on seed yield and quality of Chilli. 
M.Sc. Thesis, (Agri.), University of Agricultural Sciences, Dharwad, Karnataka, India.

Mahmood, T., Hussain, S.I., Khokhar, K.M., Hidayatullah., Bhatti, M.H. 2002. Comparative performance of local and exotic chilli cultivars. Asian Journal of Plant Sciences, 1: 162-163.

Malawadi, M.N., Shashidhara, G.B., Palled, Y.B. 2004. Effect of secondary and micronutrients on yield, nutrient uptake and quality of chilli. Karnataka Journal of Agricultural Sciences, 17: 553-556.

Malvi, U.R. 2011. Interaction of micronutrients with special reference to potassium. Karnataka Journal of Agricultural Sciences, 24: 106-109.

Malik, A., Hassan, F., Waheed, A., Qadir, G., Asghar, R. 2006. Interactive effects of irrigation and phosphorus on green gram (Vigna radiata L.). Pakistan Journal of Botany, 38: 1119-1126.

Malik, M.N. 1994. Production of Vegetable Crops. Horticulture. 511 pp., National Book Foundation, Islamabad, Pakistan.

Malik, D.M., Chaudhry, R.A., Hussain, G. 1989. Crop responses to potash application in Punjab. In: Proceedings of the Workshop on the Role of Potassium in Improving Fertilizer Use and Efficiency, pp. 7193, National Fertilizer Development Centre, Planning and Development Division, Islamabad, Pakistan.

McKenzie, R.H., Middleton, A.B., Zhang, M. 2002. Optimal time and placement of nitrogen fertilizer with direct and conventionally seeded winter wheat. Canadian Journal of Soil Science, 81: 613-621.

Miano, T.F., Tunio, S.D., Sheikh, M.A., Miano, N.M., Waggan, M.R. 2004. Effect of nitrogen and potash on the growth and yield of Chilli (Capsicum annum, L.) variety Magic Scarlet. Pakistan Journal of Agriculture Agricultural Engineering Veterinary Sciences, 20: 13-15.

Naeem, N., Irfan, M., Khan, J., Nabi, G., Muhammad, N., Badshah, N. 2002. Influence of various levels of nitrogen and phosphorus on growth and yield of chilli (Capsicum annum, L.). Asian Journal of Plant Sciences, 1: 599-601.

Olarewaju, J.D., Showemimo, F.A. 2003. Response of pepper cultivar to nitrogen and phosphorus fertilization. The Nigerian Journal of Horticultural Science, 8: $61-65$.

Paul, A.E., Berry, E.H. 1921. The Kjeldahl nitrogen method and its modifications. Journal of the Associ- ation of Official Agricultural Chemists, 5: 108-132.

Ramakrishna, T., Palled, Y.B. 2005. Effect of plant geometry and fertilizer levels on growth and yield of chilli. Karnataka Journal of Agricultural Sciences, 18: $892-895$.

Richards, L.A. 1954. Diagnosis and Improvement of Saline and Alkali Soils. USDA. Agricultural Handbook 60, Washington DC, USA.

Sajid, M., Ishtiaq, M., Amin, N., Arif, M., Rehman, Z. 2001. Effect of nitrogen and phosphorus on the growth and yield of red chillies. Sarhad Journal of Agriculture, 17: 549-551.

Satpal, G.S., Saimbhi, M.S. 2003. Effect of varying levels of nitrogen and Phosphorus on earliness and yield of brinjal hybrids (Solanum melongena L.). Research on Crops, 4: 217-222.

Singh, D.N., Sahu, A., Parida, A.K., 1999. Response of chilli (Capsicum annum L,) to applied nitrogen and potassium in clay loam soils of Orissa. Indian Journal of Agricultural Sciences, 69: 287-288.

Soltanpur, P.N. 1985. Use of ammonium bicarbonate DTPA soil test to evaluate elemental availability and toxicity. Communications in Soil and Plant Analysis, 16: 323-338.

Soltanpur, P.N., Schawab, A.P. 1977. A new soil test for simultaneous extraction of macro and micronutrients in alkaline soil. Communications in Soil and Plant Analysis, 8: 195-207.

Suresh, V.V. 2000. Effect of nitrogen and potassium on yield and quality parameters of byadagi chilli (Capsicum annuum L.). M.Sc. Thesis, (Agri.), University of Agricultural Sciences, Dharwad, Karnataka, India.

Sutagundi, R.B. 2000. Effect of mulches and nutrient management on growth and yield of chilli (Capsicum annuum L.). M.Sc. Thesis, (Agri.), University of Agricultural Sciences, Dharwad, Karnataka, India.

Vadhana, P. 2003. Response of green chilli (Capsicum annuи $\mathrm{L}$.) to Irrigation schedule and fertility levels in Vertisols. M.Sc. Thesis, (Agri.), University of Agricultural Sciences, Dharwad, Karnataka, India.

Yahaya, R.A. 2008. Effect of sheep manure, plant population and nitrogen levels on growth yield components and yield of chilli papper (Capsicum frutescence L.) Unpublished Ph.D. Dissertation. Department of Agronomy, Ahmadu Bello University Zaria, Nigeria. 